\title{
Exploring the impact of self-management of learning and personal learning initiative on mobile language learning: A moderated mediation model
}

\author{
Rui-Ting Huang \\ National Chung Hsing University, Taiwan \\ Chung-Long Yu \\ National Chung Hsing University, Taiwan
}

\begin{abstract}
Although there is a plethora of mobile learning studies, relatively little attention has been paid to the roles of self-management of learning and personal learning initiative on mobile English learning outcomes. Accordingly, the primary purpose of this study is not only to examine the links between perceived flexibility advantage, self-management of learning, mobile English learning continuance intention and performance, but also to explore the moderating role of personal learning initiative in mobile language learning outcomes. A total of 323 undergraduate students with mobile English learning experience took part in this study. The partial leastsquares structural equation modelling analysis and SPSS PROCESS (model 7) were utilised to assess the data. The study findings have not only indicated the perceived flexibility advantage and self-management of learning will have a positive influence on mobile English learning continuance intention and performance, but also revealed that mobile English learning continuance intention will mediate the link between perceived flexibility advantage and mobile English learning performance. Moreover, it has been found that personal learning initiative will play a moderating role in reinforcing the positive relationship between perceived flexibility advantage and mobile English learning continuance intention.
\end{abstract}

\section{Introduction}

Self-management of learning has been one of the focal points in previous reports, probably because it has a positive connection with learning effectiveness and efficiency (Broadbent, 2017; Rashid \& Asghar, 2016). In other words, learners with higher levels of self-management of learning will have better learning outcomes than those with lower levels of self-management of learning. For instance, previous research has not only shown that there is a positive relationship between self-management of learning and learning performance, but also revealed that self-management of learning could be positively linked to online learning satisfaction (Broadbent, 2017; Cho, Kim, \& Choi, 2017; Rashid \& Asghar, 2016). Although there is a growing interest in mobile learning studies, relatively little attention has been paid to the link between self-management of learning and mobile English learning outcomes. Accordingly, the role of self-management of learning in mobile English learning continuance intention and performance is one of the focal points in this report.

Moreover, personal learning initiative, which refers to proactive, self-starting, and persisting behaviours that learners demonstrate in order to accomplish their learning goals, is built on the concept of personal initiative (Fay \& Frese, 2001; Frese, Fay, Hilburger, Leng, \& Tag, 1997; Wang \& Li, 2015). It has been shown that personal initiative is closely linked to learning achievement. For example, Ashforth, Sluss, and Saks, (2007) have indicated that proactive behaviours positively influence newcomer learning outcomes. Wolff, Wagner, Poznanski, Schiller, and Santen (2015) have revealed that active learning leads to better knowledge acquisition and deeper understanding of learning materials. Although there are numerous mobile learning studies, relatively little attention has been paid to the moderating effect of personal learning initiative on mobile English learning effectiveness and efficiency. Accordingly, in order to close the research gap, the primary purpose of this study is not only to examine the links between perceived flexibility advantage, selfmanagement of learning, mobile English learning continuance intention and performance, but also to explore the moderating role of personal learning initiative in perceived mobile English learning performance. 


\section{Literature review and hypothesis development}

\section{Mobile learning and mobile assisted language learning}

Because of the pivotal influence of mobile technology on learning achievement, mobile learning, which is described as learning via mobile technology (Christensen \& Knezek, 2018), has gradually become an easy and convenient learning channel for people to acquire new knowledge (Clay 2011; Gedik, HanciKarademirci, Kursun, \& Cagiltay, 2012; Sung, Chang, \& Yang, 2015). Hamidi and Chavoshi (2018) added that "mobile learning is in fact a type of electronic learning which is implemented through mobile technologies such as personal digital assistants (PDA), cell phones, audio players, and electronic books etc." (p. 1054). In addition to the convenience of mobile learning, several researchers have revealed that flexibility advantages of mobile learning could play a key role in facilitating learners not only to adopt mobile learning, but also to acquire knowledge anytime and anywhere (Evans, 2008; Guo, Chang, and Lin, 2015).

Moreover, with regard to mobile language learning, it has been shown that the application of mobile technology in language learning can not only make learners more satisfied with language learning process (Chachil, Engkamat, Sarkawi, \& Shuib, 2015), but also help them achieve better language learning performance (Rahimi \& Miri, 2014). For example, Rahimi and Miri (2014) have demonstrated that in terms of language learning outcomes, mobile-assisted language learning groups outperformed traditional learning groups. Liu and Chu (2010) have shown that the use of mobile technology in language learning could be a valuable tool to help learners to continuously learn a foreign language. Additionally, Sung et al. (2015) suggested that "users can track and review learning experiences across various sites, and access learning resources that are relevant to their language skills and preferences” (p. 70. Nonetheless, the disadvantages of mobile technology, which contains short battery power and small screen size (Sarrab, Elbasir, \& Alnaeli, 2016), could still impede the adoption of mobile learning in our lives. Accordingly, in order to continuously improve mobile learning effectiveness and efficiency, the key elements that could lead to better mobile language learning outcomes should be worthy of further discussions in this report.

\section{Perceived flexibility advantage}

The perceived flexibility advantage (PFA), which originates from the concept of online learning flexibility, has been regarded as one of the key factors that could positively influence online learning outcomes (Arbaugh, 2000; Marks, Sibley, \& Arbaugh, 2005; Yukselturk \& Yildirim, 2008). Arbaugh (2000) has suggested that online courses, which provide learners with "a high degree of flexibility in when and where they participate in Internet-based courses" (p. 35), could be very helpful to busy learners. More specifically, flexibility of time and place in online learning offers another convenient solution for busy learners. Similarly, in mobile learning environments, the perceived flexibility advantage is critical to learning effectiveness and efficiency (Clay 2011; Gedik et al. 2012; Huang, Tang, Lee, \& Yang, 2017; Sung et al. 2015); that is, mobile technology enables individuals to access learning materials anytime and anywhere. This is very convenient and important for learners (Gedik et al., 2012; Hamat, Embi, \& Hassan, 2012; Sung et al., 2015), mainly because the flexibility advantage of time and place in mobile learning helps learners gain knowledge more easily and conveniently. For example, Hamat et al. (2012) have suggested that "mobile computing devices in various form factors such as tablets and smart phones have not only been a viable platform to carry out various tasks, but also being rapidly improved in terms of usability, processing power and connectivity" (p. 406). Guo et al. (2015) have added that the flexibility advantage of mobile learning could be a key factor to help students to learn new knowledge.

With particular respect to the connection between PFA, continuance intention, and learning performance, research has indicated that learning flexibility could play a key role in determining continuance intention (Chow \& Shi, 2014), and learning achievements (Agudo-Peregrina, Hernández-García, \& Pascual-Miguel, 2014). Although growing attention has been paid to the key impact of PFA on online learning (Arbaugh, 2000; Marks et al., 2005; Yukselturk \& Yildirim, 2008), there is still a shortage of research investigating the relationship between PFA, continuance intention, and learning performance. In mobile learning environments, 
it is possible that learners with higher levels of PFA could have better mobile English learning continuance intention and performance. Based on previous suggestions, accordingly, this study proposes the following hypotheses:

H1: PFA will have a positive influence on mobile English learning continuance intention.

H2: PFA will have a positive influence on perceived mobile English learning performance.

\section{Self-management of learning}

It has been found that self-management of learning (SML), which is described as "the extent to which an individual feels he or she is self-disciplined and can engage in autonomous learning” (Wang, Wu, \& Wang, 2009, p. 101), could be one of the key predictors of learning success and outcomes (Bellhäuser, Lösch, Winter, \& Schmitz, 2016; Broadbent, 2017; Rashid \& Asghar, 2016). In other words, learners with better selfmanagement of learning are more likely to achieve better learning outcomes. For instance, an educational technology report by Rashid and Asghar (2016) indicated that self-management of learning would lead to more positive academic performance. Another recent review by Broadbent (2017) suggested that selfmanagement of learning should be one of the key determinants of academic performance. Additionally, Kizilcec, Pérez-Sanagustín, and Maldonado (2017) have revealed that people with higher levels of selfregulated learning skills are likely to have better learning performance than those with lower levels of selfregulated learning skills. Gorbunovs, Kapenieks, and Cakula, (2016) have emphasised that self-discipline, especially in e-learning environments, should play a pivotal role in determining more preferable online learning outcomes.

Additionally, with respect to the role of SML in mobile learning outcomes, research has shown that there could be a positive connection between SML and mobile learning achievements. For example, Sha, Looi, Chen, Seow, and Wong (2012) have indicated that self-directed learning should be one of the key determinants of mobile learning achievements. Ko, Chiu, Lo, and Ho (2015) have revealed that "based on the autonomy feature of m-learning that allows learners to take charge of their own learning progress, it is generally agreed that m-learning is more suitable for self-regulated learning” (p. 568). Moreover, Dold (2016) has suggested that in mobile learning environments, self-directed learning will help learners achieve better and deeper learning outcomes. Although there is a growing interest in mobile-assisted language learning studies, limited efforts have been made to investigate the impact of SML on mobile language learning performance. Accordingly, in order to further examine the role of SML in perceived mobile English learning outcomes, this study proposes the following hypotheses:

H3: SML will have a positive influence on mobile English learning continuance intention.

H4: SML will have a positive influence on perceived mobile English learning performance.

\section{Mobile learning continuance intention and performance}

The continuance intention of information technology is gradually receiving more attention, probably because it could be one of the central determinants of learning outcomes (Lin, 2012) and individual performance (Mohammadyari \& Singh, 2015). For example, a web-based learning report by Lin (2012) has found that the continuance intention of virtual learning systems could be positively connected with perceived impacts on learning. Another recent study by Mohammadyari and Singh (2015) has suggested that "the more frequently a technology is used, the better it meets the characteristics of the work and task, leading to a higher probability that the technology will improve job performance" (p. 16). Additionally, in regard to the definition of continuance intention, Wang and Chiang (2009) suggested that "continuance intention to usage is a conceptually distinct construct from initial adoption” (p. 468). Lin (2012) defined the continuance intention of an information system as "the continued usage of IS by adopters, where a continuance decision follows an initial acceptance decision” (p. 500). 
Similarly, in mobile language learning environments, mobile English learning continuance intention, which is described as learners' continuance intention to adopt mobile technology to learn English, could play a key role in determining mobile language learning performance, which includes listening, speaking, reading and writing performance (Huang, Jang, Machtmes, \& Deggs, 2012). That is, it is likely that learners with better mobile English learning continuance intention have better perceived mobile English learning performance. Although several reports have focused on the critical role of continuance intention in online learning studies, relatively little attention has been placed on the relationship between mobile English learning continuance intention and performance. Accordingly, based on previous suggestions, this study proposes the following hypotheses:

H5: Mobile English learning continuance intention will have a positive impact on perceived mobile English learning performance.

H6: Mobile English learning continuance intention will mediate the link between PFAs and perceived mobile English learning performance.

\section{Personal learning initiative}

Personal learning initiative (PLI), which involves learners proactively acquiring new knowledge and overcoming learning obstacles, is derived from the concept of personal initiative (Fay \& Frese, 2001; Frese et al., 1997). Fay and Frese (2001) define personal initiative as "a behavior syndrome that results in an individual taking an active and self-starting approach to work goals and tasks and persisting in overcoming barriers and setbacks" (p. 97). In addition to proactive and persistent behaviour, a report by Fay and Frese (2001) has revealed that one of the key components in personal initiative is closely linked to the concept of self-starting behaviour, which "implies that the goals are not given or assigned by someone else, but that the person himself or herself develops these goals" (p. 98). Another organisational study by Wang and Li (2015) has added that "personal initiative refers to proactive, self-starting, and persisting behaviors that employees enact to achieve their work goals" (p. 136). Likewise, in learning environments, PLI could play a central part in learning achievement. More specifically, in order to achieve learning goals, learners with better PLI are more likely to have the initiative to acquire knowledge and proactively overcome learning obstacles, which in turn will lead to better learning performance.

Second, in regard to the critical impact of PLI on mobile learning, research has shown that PLI could be positively connected with learning outcomes (Ashforth et al., 2007; Kim, Lee, \& Ryu, 2013; Pawlowska, Westerman, Bergman, \& Huelsman, 2014; Wolff et al., 2015). For example, a review by Ashforth et al. (2007) has suggested that proactive behaviours are closely linked to newcomer learning outcomes. Another recent report, by Wolff et al. (2015), has revealed that active learning leads to better knowledge acquisition and deeper understanding of learning materials. Additionally, Mouza and Barrett-Greenly (2015) have indicated that mobile learning initiatives could positively predict learning achievements. More importantly, Huang, Tang, Lee, and Yang (2017) have shown that proactive personality could play a moderating role in determining mobile learning outcomes.

In mobile language learning environments, although it is likely that learners with higher levels of PLI will lead to better connection between PFA and mobile English learning continuance intention, little has been known about the moderating effect of PLI on mobile English learning outcomes. Consequently, based on previous suggestions, this study proposes the following hypothesis and theoretical framework (see Figure 1):

H7: PLI will moderate the relationship between PFA and mobile English learning continuance intention. 


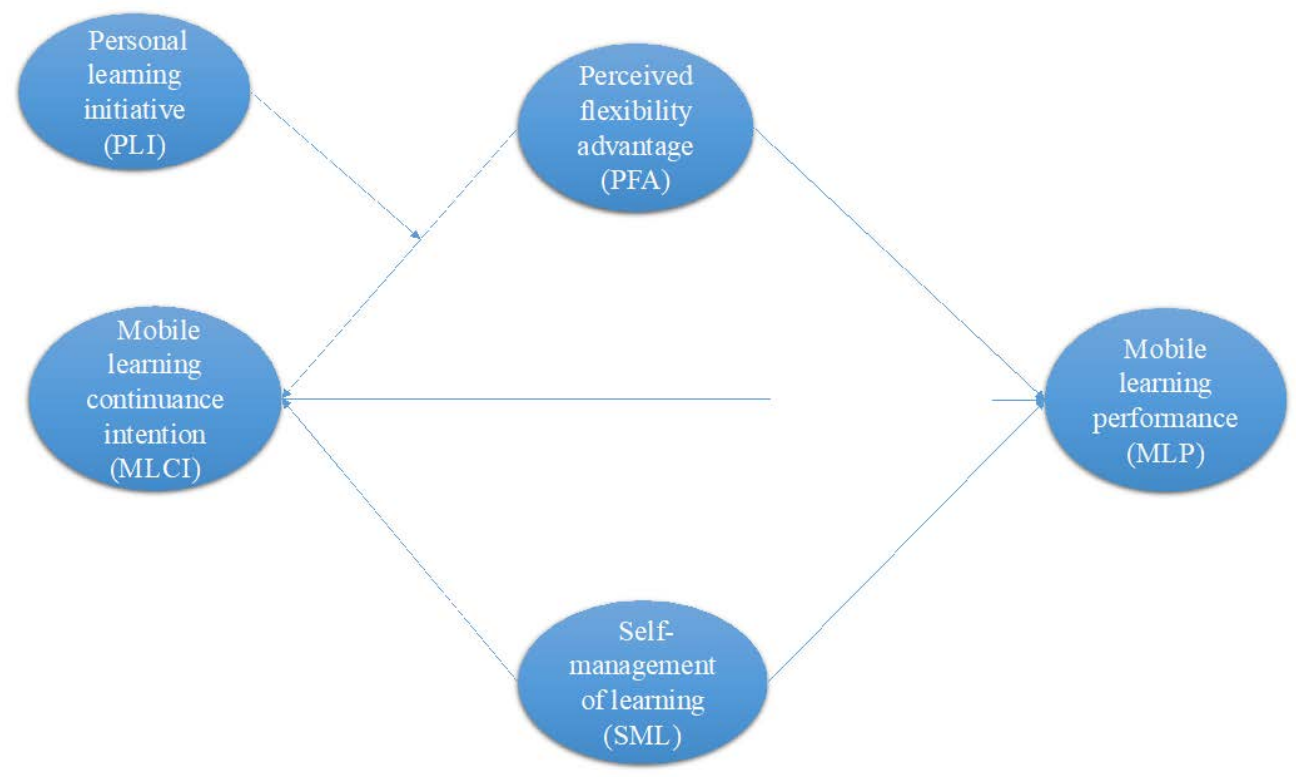

Figure 1. Research framework of the study

\section{Research methodology}

\section{Demographic data for respondents}

Except for three pieces of missing data (1\%), shown in Table 1, the participants consisted of 93 males (29\%), and 227 females (70\%). The majority of participants (58\%) were sophomores, and most students (46\%) had used a mobile phone to learn English before. Finally, the mean age and standard deviation of the participants were 20.76 and 4.67 , respectively.

Table 1

Demographic data for respondents

\begin{tabular}{llcc}
\hline Demographics & Items & Number & Percentage of respondents \\
\hline Gender & Male & 93 & 29 \\
& Female & 227 & 70 \\
Age & Missing data & 3 & 1 \\
& Valid participants & 317 & 98 \\
& Missing data & 6 & 2 \\
\multirow{5}{*}{ Mobile devices } & 20.76 & \\
& Mean age & 4.67 & 32 \\
& Standard deviation & 104 & 46 \\
& Notebook computer & 149 & 22 \\
& Mobile phone & 70 & 12 \\
& Others (PDA, electronic dictionaries) & 37 & 58 \\
& Freshman & 190 & 11 \\
& Sophomore & 35 & 17 \\
& Junior & 54 & 2 \\
& Senior & 7 & \\
& Missing data & & \\
\hline
\end{tabular}




\section{Data collection}

This study simultaneously gathered the data from three universities in Taiwan. Undergraduate students with mobile English learning experience were invited to complete the mobile learning survey. Specifically, the first question in the survey, which asked "Have you ever used mobile technology to learn English before", was adopted to screen out those participants without mobile English learning experience. A total of 600 surveys were handed out to students. The total number of usable responses was 323.

\section{Instrumentation}

In order to evaluate key variables, survey items were adopted from different psychological reports and mobile learning studies. As shown in Table 2, a 7-point Likert scale, which ranged from " 1 = strongly disagree" to "7 = strongly agree", was employed to assess different constructs in this research. The survey items of PFA were taken from Marks et al. (2005). Sample items are "Using mobile technology could allow me to arrange my English learning time more easily", and "Using mobile technology could enable me to arrange English learning schedule more flexibly". In addition, six items which evaluated PLI were taken from Frese et al. (1997). Sample items are "I actively deal with problems encountered in learning", and "Whenever learning goes wrong, I search for a solution immediately". Third, survey items which examined the construct of SML were developed from Wang et al. (2009). Sample items are "When it comes to learning and studying, I am a self-directed person", and "In my studies, I am self-disciplined and find it easy to set aside reading and homework time”. Moreover, survey items which assessed mobile English learning continuance intention were developed from Roca, Chiu, and Martínez (2006). Sample items are "I will continue to use mobile technology to learn English in the future", and "I intend to regularly use mobile technology to learn English". Finally, five survey items were adopted from Huang et al. (2012) to evaluate the construct of perceived mobile English learning performance. Sample items are "Using mobile technology to learn English helps me upgrade my listening ability", and "Overall, using mobile technology to learn English helps me improve my English ability".

\section{Data analysis and results}

This study adopted SPSS and visual PLS software to analyse the demographic variables and examine the relationship between PFA, PLI, and mobile learning outcomes. The partial least-squares structural equation modelling (PLS-SEM) analysis was utilised to assess the data, not only because it is a widely accepted structural equation modelling technique, but also because it is very suitable for studies which concentrate on theoretical development (Lu, Ma, Turner, \& Huang, 2007). First, in order to assess the measurement model, the composite reliability (CR) and factor loading were utilised to determine whether the reliability and internal consistency of the instrument were satisfactory. As shown in Table 2, the CR of each variable exceeded .80, and all factor loadings were larger than .70. Therefore, it was concluded that the internal consistency of the instrument was acceptable (Fornell \& Larcker, 1981). 
Table 2

Confirmatory factor analysis

\begin{tabular}{|c|c|c|c|c|}
\hline Items & Factor loading & $\mathbf{C R}$ & AVE & $\alpha$ \\
\hline $\begin{array}{l}\text { PFA1 Using mobile technology could allow me to arrange my } \\
\text { English learning time more easily. }\end{array}$ & .83 & \multirow{4}{*}{.90} & \multirow{4}{*}{.71} & \multirow{4}{*}{.86} \\
\hline PFA2 Using mobile technology could enable me to arrange & .86 & & & \\
\hline $\begin{array}{l}\text { English learning schedule more flexibly. } \\
\text { PFA3 Using mobile technology could let me use time to learn } \\
\text { English more efficiently. }\end{array}$ & .90 & & & \\
\hline $\begin{array}{l}\text { PFA4 Using mobile technology could enable me to learn } \\
\text { English anytime and anywhere. }\end{array}$ & .76 & & & \\
\hline $\begin{array}{l}\text { MLCI1 I will continue to use mobile technology to learn } \\
\text { English in the future. }\end{array}$ & .90 & \multirow{3}{*}{.93} & \multirow{3}{*}{.83} & \multirow{3}{*}{.90} \\
\hline $\begin{array}{l}\text { MLCI2 I intend to regularly use mobile technology to learn } \\
\text { English. }\end{array}$ & .93 & & & \\
\hline $\begin{array}{l}\text { MLCI3 I would recommend to other students to use mobile } \\
\text { technology to learn English. }\end{array}$ & .90 & & & \\
\hline $\begin{array}{l}\text { PMELP1 Using mobile technology to learn English helps me } \\
\text { upgrade my listening ability. }\end{array}$ & .85 & \multirow{5}{*}{.93} & \multirow{5}{*}{.72} & \multirow{5}{*}{.90} \\
\hline $\begin{array}{l}\text { PMELP2 Using mobile technology to learn English helps me } \\
\text { improve my speaking ability. }\end{array}$ & .84 & & & \\
\hline $\begin{array}{l}\text { PMELP3 Using mobile technology to learn English helps me } \\
\text { enhance my reading ability. }\end{array}$ & .89 & & & \\
\hline $\begin{array}{l}\text { PMELP4 Using mobile technology to learn English helps me } \\
\text { improve my writing ability. }\end{array}$ & .80 & & & \\
\hline $\begin{array}{l}\text { PMELP5 Overall, using mobile technology to learn English } \\
\text { helps me improve my English ability. }\end{array}$ & .86 & & & \\
\hline $\begin{array}{l}\text { SML1 When it comes to learning and studying, I am a self- } \\
\text { directed person. }\end{array}$ & .86 & \multirow{4}{*}{.94} & \multirow{4}{*}{.80} & \multirow{4}{*}{.92} \\
\hline $\begin{array}{l}\text { SML2 In my studies, I am self-disciplined and find it easy to } \\
\text { set aside reading and homework time. }\end{array}$ & .89 & & & \\
\hline $\begin{array}{l}\text { SML3 I am able to manage my study time effectively and } \\
\text { easily complete assignments on time. }\end{array}$ & .91 & & & \\
\hline $\begin{array}{l}\text { SML4 In my studies, I set goals and have a high degree of } \\
\text { initiative. }\end{array}$ & .91 & & & \\
\hline PLI1 I actively deal with problems encountered in learning. & .87 & \multirow{6}{*}{.94} & \multirow{6}{*}{.73} & \multirow{6}{*}{.92} \\
\hline $\begin{array}{l}\text { PLI2 Whenever learning goes wrong, I search for a solution } \\
\text { immediately. }\end{array}$ & .86 & & & \\
\hline $\begin{array}{l}\text { PLI3Whenever there is a chance to get actively involved in } \\
\text { new learning activities, I take it. }\end{array}$ & .88 & & & \\
\hline $\begin{array}{l}\text { PLI4 With respect to the acquisition of new knowledge, I take } \\
\text { the initiative immediately even when others don't. }\end{array}$ & .84 & & & \\
\hline $\begin{array}{l}\text { PLI5 I use possible learning opportunities quickly in order to } \\
\text { attain my learning goals. }\end{array}$ & .85 & & & \\
\hline PLI6 I am particularly good at realising my learning ides. & .81 & & & \\
\hline
\end{tabular}

Note. PFA, perceived flexibility advantage; SML, self-management of learning; PLI, personal learning initiative; MELCI, mobile English learning continuance intention; PMELP, perceived mobile English learning performance; CR, composite reliability; AVE, average variance extracted; $\alpha$, Cronbach's alpha.

In addition, the values of average variance extracted (AVE) and square root of AVE were used to examine the adequacy of convergent and discriminant validity in this study. As shown in Tables 2 and 3, the convergent and discriminant validity was satisfactory, mainly because the values of AVE were well above the suggested criteria of .50, and the square root of AVE on the diagonal all exceeded off-diagonal correlation values 
between different constructs (Fornell \& Larcker, 1981). Accordingly, it was shown that the measurement model was acceptable.

Table 3

The correlations of each construct

\begin{tabular}{lrrrrr}
\hline Construct & MELCI & PFA & PLI & PMELP & SML \\
\hline MELCI & .91 & & & & \\
PFA & .60 & .84 & & & \\
PLI & .46 & .36 & .85 & .85 & \\
PMLP & .74 & .55 & .47 & .48 & .89 \\
SML & .45 & .40 & .73 & .48 \\
\hline
\end{tabular}

Note. PFA, perceived flexibility advantage; SML, self-management of learning; PLI, personal learning initiative; MELCI, mobile English learning continuance intention; PMELP, perceived mobile English learning performance; Diagonal elements are the square root of AVE.

Moreover, with respect to the structural model and hypothesis testing, the $t$-values, path coefficients and Rsquare values were used to assess whether the hypotheses were supported by the study findings, and further examine the relationship between key mobile learning variables and performance. As shown in Figure 2, hypotheses 1, 2, 3, 4 and 5 were all supported by the study findings. The study findings indicated that PFA (H2; $\beta=.504, t=8.264$ ) and SML (H4; $\beta=.249, t=3.619$ ), which accounted for a total of $41.8 \%$ of variance in continuance intention, would have a positive influence on mobile English learning continuance intention. Moreover, the PFA (H1; $\beta=.127, t=2.213$ ), mobile English learning continuance intention (H5; $\beta=.598, t=$ 10.497), and SML (H3; $\beta=.159, t=2.989$ ), which explained a total of $59.4 \%$ of variance in perceived mobile English learning performance, would play a key role in determining mobile language learning performance.

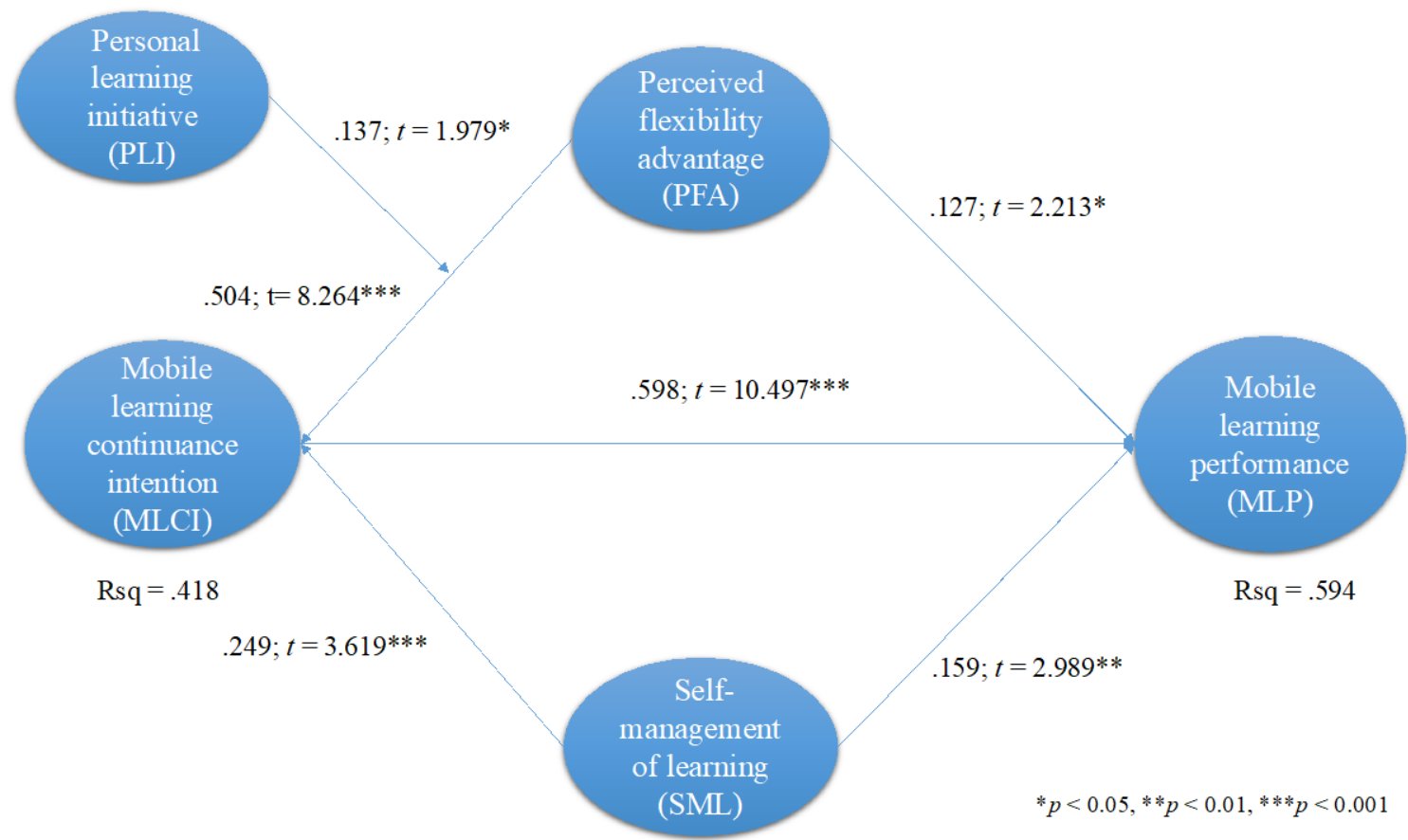

Figure 2. The path coefficient, R-square and t-values 
Finally, in order to investigate the mediating role of continuance intention, and moderating role of PLI in this study, SPSS PROCESS procedure (model 7) and 5000 bootstrap samples were adopted to examine the moderated mediation effects (Hayes, 2013). As shown in Table 4, the study findings revealed that PLI would play a moderating role in determining the link between PFA and mobile English learning continuance intention $(\mathrm{H} 7 ; \beta=.1373, \mathrm{t}=1.979)$.

Table 4

Moderated mediation model

\begin{tabular}{|c|c|c|c|c|c|c|}
\hline & $\beta$ & SE & $t$ & $p$ & LLCI & ULCI \\
\hline \multicolumn{7}{|c|}{ Mediator variable model (MELCI) } \\
\hline Constant & 4.318 & .3919 & 11.006 & .0000 & 3.5398 & 5.0817 \\
\hline PFA & 5391 & .0661 & 8.1613 & .0000 & 4091 & 6690 \\
\hline PLI & 2454 & 0911 & 2.6939 & .0074 & 0662 & 4246 \\
\hline PFA * PLI & 1373 & .0694 & 1.9791 & .0487 & .0008 & 2738 \\
\hline SML & .0802 & .0851 & .9427 & .3465 & -.0872 & .2476 \\
\hline \multicolumn{7}{|c|}{ Dependent variable model (PMELP) } \\
\hline Constant & 1.2803 & .3469 & 3.6914 & .0003 & .5979 & 1.9628 \\
\hline MELCI & 5356 & .0637 & 8.4062 & .0000 & 4102 & 6110 \\
\hline PFA & 1301 & .0656 & 1.9816 & .0484 & .0009 & 2592 \\
\hline SML & 1528 & .0519 & 2.9449 & .0035 & .0507 & 2550 \\
\hline
\end{tabular}

Note. PFA, perceived flexibility advantage; PLI, personal learning initiative; SML, self-management of learning; MELCI, mobile English learning continuance intention; PMELP, perceived mobile English learning performance; LLCI, low limit confidence interval; ULCI, upper limit confidence interval.

More importantly, it was shown that mobile English learning continuance intention would mediate the link between PFA and perceived mobile English learning performance, because 0 was not contained in different confidence intervals (95\% CI) (Table 5). Accordingly, it was demonstrated that hypothesis 6 and 7 were all supported by the study results (Hayes, 2013).

Table 5

Direct and conditional indirect effects

\begin{tabular}{|c|c|c|c|c|c|c|}
\hline \multicolumn{7}{|c|}{ Direct effect of PFA on PMELP } \\
\hline & Effect & SE (Boot) & $t$ & $p$ & Boot LLCI & Boot ULCI \\
\hline & 1301 & .0656 & 1.9816 & .0484 & .0009 & 2592 \\
\hline \multicolumn{7}{|c|}{ Conditional indirect effects } \\
\hline Mediator & PLI & & Effect & SE (Boot) & Boot LLCI & Boot ULCI \\
\hline MELCI & -1.0252 & & 2133 & 0657 & 0967 & .3535 \\
\hline MELCI & .0000 & & 2887 & .0505 & 1970 & 3934 \\
\hline MELCI & 1.0252 & & 3641 & 0548 & 2627 & 4793 \\
\hline \multicolumn{7}{|c|}{ Index of moderated-mediation } \\
\hline Mediator & & & Index & SE (Boot) & Boot LLCI & Boot ULCI \\
\hline MELCI & & & 0735 & 0325 & 0132 & 1418 \\
\hline
\end{tabular}

Note. Values for PLI and SML are the mean and plus/minus one SD from mean; PFA, perceived flexibility advantage; PLI, personal learning initiative; SML, self-management of learning; MELCI, mobile English learning continuance intention; PMELP, perceived mobile English learning performance.

\section{Discussions and implications}

\section{Summary of findings}

The primary purpose of this study is not only to examine the links between PFA, SML, mobile English learning continuance intention and performance, but also to explore the moderating role of PLI in perceived mobile English learning performance. First, the study findings, consistent with previous reports (Agudo- 
Peregrina et al., 2014; Bellhäuser et al., 2016; Broadbent, 2017; Chow \& Shi, 2014; Rashid \& Asghar, 2016), indicated that PFA and SML have a positive influence on mobile English learning continuance intention. That is, learners with higher levels of PFA and SML are more likely to have better mobile English learning continuance intention. Second, it has been found that PFA, mobile English learning continuance intention, and SML will have a positive impact on perceived mobile English learning performance. Third, the study results are in line with previous studies (Ashforth et al., 2007; Wolff et al., 2015), which reveal that PLI will moderate the link between PFA and mobile English learning continuance intention. More precisely, PLI could be regarded as a moderating force which strengthens the relationship between PFA and mobile English learning continuance intention. Finally, the study findings are congruent with previous reports (Lin, 2012; Mohammadyari \& Singh, 2015), which indicate that mobile English learning continuance intention will mediate the link between PFA and mobile English learning performance. In other words, learners with higher levels of PFA will have better mobile English learning continuance intention, which in turn would lead to more positive perceived mobile English learning performance.

\section{Limitations and suggestions}

One of this study's limitations is the limited size of data sampling. With specific regard to the impact of gender on mobile learning performance, the study findings should be interpreted very carefully, mainly because $70 \%$ of the participants were females. Hence, in terms of the generalisability of the study findings, it is suggested that more research is needed to verify the roles of SML and PLI in mobile learning performance. Another limitation in this study is closely related to the measurement of mobile learning outcomes. Specifically, this study utilised only individuals' perceived learning outcomes to evaluate mobile English learning performance. In order to more precisely examine the learning outcomes, it is suggested that formal tests should be adopted to evaluate students learning achievement. Moreover, because this study adopted only quantitative methods to collect and analyse the data, it is suggested that future research should adopt a bricolage of mixed methods to ascertain deeper insights into phenomena. For example, in addition to quantitative methods, qualitative methods such as focus groups and observations could be utilised to get further and deeper learning evidence from participants. Finally, demographic variables such as prior experience with mobile technology, and language learning experience were neglected in this study. Accordingly, it is suggested that more attention should be paid to investigating the critical impacts of prior experience with mobile technology and language learning experience on mobile learning outcomes.

\section{Theoretical and practical implications}

First, with regard to the role of PFA in mobile learning outcomes, although previous reports have indicated the key influence of PFA on online learning (Arbaugh, 2000; Marks et al., 2005; Yukselturk \& Yildirim, 2008), there is still a shortage of research investigating the association between PFA, mobile learning continuance intention and performance. The study findings here have demonstrated that the flexibility advantage of time and place in mobile learning could be one of the key elements in enhancing mobile learning outcomes (Agudo-Peregrina et al., 2014; Chow \& Shi, 2014). Hence, it is suggested that more effort should be devoted to facilitating learners to adopt mobile technology, mainly because the flexibility advantage of time and place could play a key role in determining mobile English learning continuance intention and performance. For example, learning institutions and organisations could offer learners free mobile devices in order to help them to acquire knowledge and further improve mobile learning effectiveness and efficiency.

Second, it has been shown that SML will play a key role in determining mobile English learning continuance intention and perceived mobile English learning performance (Bellhäuser et al., 2016; Broadbent, 2017; Rashid \& Asghar, 2016). Specifically, learners with better SML will have more preferable mobile language learning outcomes. Hence, it is suggested that instructors and learning facilitators should suggest that learners with better SML adopt mobile learning, due mainly to its impact on mobile language learning performance. More importantly, it is suggested that free training programs, related to "self-assessment and task-selection skills” (Huang, 2014, p. 263), could be offered by learning institutions and organisations to help learners to improve SML and benefit from mobile learning. 
Third, although there is a plethora of mobile learning studies, limited efforts have been devoted to the moderating role of PLI on mobile language learning outcomes. The study results here show that the PLI could play a key role in reinforcing the link between PFA and mobile English learning continuance intention (Ashforth et al., 2007; Wolff et al., 2015). That is, it is likely that learners with higher levels of PLI will have better perceived mobile language learning performance, probably because they have a stronger connection between PFA and mobile English learning continuance intention. Due mainly to the close association between personality traits and learning achievement (Kim et al., 2013; Pawlowska et al., 2014), more attention should be paid to the moderating impact of PLI on mobile language learning outcomes. For example, with particular respect to those learners with higher levels of PLI, it is suggested that timely supports from learning institutions, and positive suggestions and feedback from instructors should be adopted to help them engage in mobile learning and further achieve better language learning performance (Huang et al., 2017; Mouza \& Barrett-Greenly, 2015). Additionally, research has shown that curiosity could be one of the key factors influencing personal initiative (Wang \& Li, 2015). Consequently, it is important that more efforts be devoted to investigating the link between curiosity and PLI.

Last but not least, the study findings here have demonstrated that mobile English learning continuance intention not only positively predicts perceived mobile English learning performance, but also mediates the link between PFA and mobile English learning performance (Lin, 2012; Mohammadyari \& Singh, 2015). In other words, it is possible for learners with better mobile English learning continuance intention to achieve better mobile English learning performance. It is suggested that more research should be done to investigate the key factors that enhance mobile language learning continuance intention, owing to its critical role in language learning performance. More importantly, in order to improve mobile language learning performance, more efforts should be made to help learners continuously adopt mobile language learning in the future.

\section{Conclusion}

The findings of this study not only add to the body of knowledge in the mobile language learning field, but also offer instructors and learning institutions practical solutions to improve mobile language learning performance. More importantly, the moderating impact of PLI on relationship between PFA and mobile English learning continuance intention has been verified through empirical examinations. As mobile devices have gradually become critical learning tools, it is important that more effort should be devoted to exploring the key moderating factors for improving mobile learning effectiveness and efficiency.

\section{References}

Agudo-Peregrina, Á. F., Hernández-García, Á., \& Pascual-Miguel, F. J. (2014). Behavioral intention, use behavior and the acceptance of electronic learning systems: Differences between higher education and lifelong learning. Computers in Human Behavior, 34, 301-314. https://doi.org/10.1016/j.chb.2013.10.035

Arbaugh, J. B. (2000). Virtual classroom characteristics and student satisfaction with Internet based MBA courses. Journal of Management Education, 24 (1), 32-54. https://doi.org/10.1177/105256290002400104

Ashforth, B. E., Sluss, D. M., Saks, A. M. (2007). Socialization tactics, proactive behavior, and newcomer learning: Integrating socialization models. Journal of Vocational Behavior, 70(3), 447-462. https://doi.org/10.1016/j.jvb.2007.02.001

Bellhäuser, H., Lösch, T., Winter, C., \& Schmitz, B. (2016). Applying a web-based training to foster selfregulated learning: Effects of an intervention for large numbers of participants. The Internet and Higher Education, 31, 87-100. https://doi.org/10.1016/j.iheduc.2016.07.002

Broadbent, J. (2017). Comparing online and blended learner's self-regulated learning strategies and academic performance. The Internet and Higher Education, 33, 24-32. https://doi.org/10.1016/j.iheduc.2017.01.004

Chachil, K., Engkamat, A., Sarkawi, A., \& Shuib, A. R. A. (2015). Interactive multimedia-based mobile application for learning Iban language (I-MMAPS for Learning Iban Language). Procedia - Social and Behavioral Sciences, 167, 267-273. https://doi.org/10.1016/j.sbspro.2014.12.673 
Cho, M.-H., Kim, Y., \& Choi, D. (2017). The effect of self-regulated learning on college students' perceptions of community of inquiry and affective outcomes in online learning. The Internet and Higher Education, 34, 10-17. https://doi.org/10.1016/j.iheduc.2017.04.001

Chow, W. S., \& Shi, S. (2014). Investigating students' satisfaction and continuance intention toward elearning: An extension of the expectation-confirmation model. Procedia - Social and Behavioral Sciences, 141, 1145-1149. https://doi.org/10.1016/j.sbspro.2014.05.193

Christensen, R., \& Knezek, G. (2018). Reprint of Readiness for integrating mobile learning in the classroom: Challenges, preferences and possibilities. Computers in Human Behavior, 78, 379-388. https://doi.org/10.1016/j.chb.2017.07.046

Clay, C. A. (2011). Exploring the use of mobile technologies for the acquisition of clinical skills. Nurse Education Today, 31(6), 582-586. https://doi.org/10.1016/j.nedt.2010.10.011

Dold, C. J. (2016). Rethinking mobile learning in light of current theories and studies. The Journal of Academic Librarianship, 42(6), 679-686. https://doi.org/10.1016/j.acalib.2016.08.004

Evans, C. (2008). The effectiveness of m-learning in the form of podcast revision lectures in higher education. Computers \& Education, 50(2), 491-498. https://doi.org/10.1016/j.compedu.2007.09.016

Fay, D., \& Frese, M. (2001). The concept of personal initiative: An overview of validity studies. Human Performance, 14(1), 97-124. https://doi.org/10.1207/S15327043HUP1401_06

Fornell, C., \& Larcker, D. F. (1981). Evaluating structural equation models with unobservable and measurement error. Journal of Marketing Research, 18(1), 39-50. http://dx.doi.org/10.2307/3151312

Frese, M., Fay, D., Hilburger, T., Leng, K., \& Tag, A. (1997). The concept of personal initiative: Operationalization, reliability and validity in two German samples. Journal of Organizational and Occupational Psychology, 70, 139-161. http://doi.org/10.1111/j.2044-8325.1997.tb00639.x

Gedik, N., Hanci-Karademirci, A., Kursun, E., \& Cagiltay, K. (2012). Key instructional design issues in a cellular phone-based mobile learning project. Computers \& Education, 58(4),1149-1159. https://doi.org/10.1016/j.compedu.2011.12.002

Gorbunovs, A., Kapenieks, A., \& Cakula, S. (2016). Self-discipline as a key indicator to improve learning outcomes in e-learning environment. Procedia - Social and Behavioral Sciences, 231, 256-262. https://doi.org/10.1016/j.sbspro.2016.09.100

Guo, S. H.-M., Chang, H.-K., \& Lin, C.-Y. (2015). Impact of mobile diabetes self-care system on patients' knowledge, behavior and efficacy. Computers in Industry, 69, 22-29. https://doi.org/10.1016/j.compind.2014.11.001

Hamat, A., Embi, M. A., \& Hassan, H. A. (2012). Mobile learning readiness among UKM lecturers. Procedia - Social and Behavioral Sciences, 59, 406-410. https://doi.org/10.1016/j.sbspro.2012.09.294

Hamidi, H., \& Chavoshi, A. (2018). Analysis of the essential factors for the adoption of mobile learning in higher education: A case study of students of the University of Technology. Telematics and Informatics, 35(4), 1053-1070. https://doi.org/10.1016/j.tele.2017.09.016

Hayes, A. F. (2013). Introduction to mediation, moderation, and conditional process analysis: A regressionbased approach. New York, NY: The Guilford Press.

Huang, R.-T. (2014). Exploring the moderating role of self-management of learning in mobile English learning. Journal of Educational Technology \& Society, 17(4), 255-267. Retrieved from https://www.jets.net/ETS/journals/17 4/17.pdf

Huang, R.-T., Jang, S.-J., Machtmes, K., \& Deggs, D. (2012). Investigating the roles of perceived playfulness, resistance to change, and self-management of learning in mobile English learning outcome. British Journal of Educational Technology, 43(6), 1004-1015. https://doi.org/10.1111/j.1467-8535.2011.01239.x

Huang, R.-T., Tang, T.-W., Lee, Y. P., \& Yang, F.-Y. (2017). Does proactive personality matter in mobile learning? Australasian Journal of Educational Technology, 33(2), 86-96. https://doi.org/10.14742/ajet.2896

Kim, J., Lee, A., \& Ryu, H. (2013). Personality and its effects on learning performance: Design guidelines for an adaptive e-learning system based on a user model. International Journal of Industrial Ergonomics, 43(5), 450-461. https://doi.org/10.1016/j.ergon.2013.03.001

Kizilcec, R. F., Pérez-Sanagustín, M., \& Maldonado, J. J. (2017). Self-regulated learning strategies predict learner behavior and goal attainment in massive open online courses. Computers \& Education, 104, 18 33. https://doi.org/10.1016/j.compedu.2016.10.001 
Ko, E. H. T., Chiu, D. K. W., Lo, P., \& Ho, K. K. W. (2015). Comparative study on m-Learning usage among LIS students from Hong Kong, Japan and Taiwan. The Journal of Academic Librarianship, 41(5), 567577. https://doi.org/10.1016/j.acalib.2015.07.005

Lin, W.-S. (2012). Perceived fit and satisfaction on web learning performance: IS continuance intention and task-technology fit perspectives. International Journal of Human-Computer Studies, 70(7), 498-507. https://doi.org/10.1016/j.ijhcs.2012.01.006

Liu, T.-Y., \& Chu, Y.-L. (2010). Using ubiquitous games in an English listening and speaking course: Impact on learning outcomes and motivation. Computers \& Education, 55, 630-643. https://doi.org/10.1016/j.compedu.2010.02.023

Lu, E. Y., Ma, H., Turner, S., \& Huang, W. (2007). Wireless Internet and student-centered learning: A partial least-squares model. Computers \& Education, 49(2), 530-544. https://doi.org/10.1016/j.compedu.2005.10.009

Marks, R. B., Sibley, S. D., \& Arbaugh, J. B. (2005). A structural equation model of predictors for effective online learning. Journal of Management Education, 29(4), 531-563. https://doi.org/10.1177/1052562904271199

Mohammadyari, S. \& Singh, H. (2015). Understanding the effect of e-learning on individual performance: The role of digital literacy. Computers \& Education, 82, 11-25. https://doi.org/10.1016/j.compedu.2014.10.025

Mouza, C., \& Barrett-Greenly, T. (2015). Bridging the app gap: An examination of a professional development initiative on mobile learning in urban schools. Computers \& Education, 88, 1-14. https://doi.org/10.1016/j.compedu.2015.04.009

Pawlowska, D. K., Westerman, J. W., Bergman, S. M., \& Huelsman, T. J. (2014). Student personality, classroom environment, and student outcomes: A person-environment fit analysis. Learning and Individual Differences, 36, 180-193. https://doi.org/10.1016/j.lindif.2014.10.005

Rahimi, M., \& Miri, S. S. (2014). The impact of mobile dictionary use on language learning. Procedia Social and Behavioral Sciences, 98, 1469-1474. https://doi.org/10.1016/j.sbspro.2014.03.567

Rashid, T., \& Asghar, H. M. (2016). Technology use, self-directed learning, student engagement and academic performance: Examining the interrelations. Computers in Human Behavior, 63, 604-612. https://doi.org/10.1016/j.chb.2016.05.084

Roca, J. C., Chiu, C. M., \& Martínez, F. J. (2006). Understanding e-learning continuance intention: An extension of the technology acceptance model. International Journal of Human-Computer Studies, 64(8), 683-696. https://doi.org/10.1016/j.ijhcs.2006.01.003

Sarrab, M., Elbasir, M., \& Alnaeli, S. (2016). Towards a quality model of technical aspects for mobile learning services: An empirical investigation. Computers in Human Behavior, 55, 100-112. https://doi.org/10.1016/j.chb.2015.09.003

Sha, L., Looi, C-K., Chen, W., Seow, P., \& Wong, L-H. (2012). Recognizing and measuring self-regulated learning in a mobile learning environment. Computers in Human Behavior, 28(2), 718-728. https://doi.org/10.1016/j.chb.2011.11.019

Sung, Y-T., Chang, K-E., \& Yang, J-M. (2015). How effective are mobile devices for language learning? A meta-analysis. Educational Research Review, 16, 68-84. https://doi.org/10.1016/j.edurev.2015.09.001

Wang, H., \& Li, J. (2015). How trait curiosity influences psychological well-being and emotional exhaustion: The mediating role of personal initiative. Personality and Individual Differences, 75, 135-140. https://doi.org/10.1016/j.paid.2014.11.020

Wang, J-C., \& Chiang, M-J. (2009). Social interaction and continuance intention in online auctions: A social capital perspective. Decision Support Systems, 47(4), 466-476. https://doi.org/10.1016/j.dss.2009.04.013

Wang, Y., Wu, M., \& Wang, H. (2009). Investigating the determinants and age and gender differences in the acceptance of mobile learning. British Journal of Educational Technology, 40(1), 92-118. https://doi.org/10.1111/j.1467-8535.2007.00809.x

Wolff, M., Wagner, M. J., Poznanski, S., Schiller, J., Santen, S. (2015). Not another boring lecture: Engaging learners with active learning techniques. The Journal of Emergency Medicine, 48(1), 85-93. https://doi.org/10.1016/j.jemermed.2014.09.010

Yukselturk, E., \& Yildirim, Z. (2008). Investigation of interaction, online support, course structure and flexibility as the contributing factors to students' satisfaction in an online certificate program. Educational Technology \& Society, 11(4), 51-65. Retrieved from https://www.jstor.org/stable/jeductechsoci.11.4.51 
Corresponding author: Rui-Ting Huang, rthuang0324@dragon.nchu.edu.tw

Australasian Journal of Educational Technology @ 2019.

Please cite as: Huang, R.-T., \& Yu, C.-L. (2019). Exploring the impact of self-management of learning and personal learning initiative on mobile language learning: A moderated mediation model. Australasian Journal of Educational Technology, 35(3), 118-131. https://doi.org/10.14742/ajet.4188 